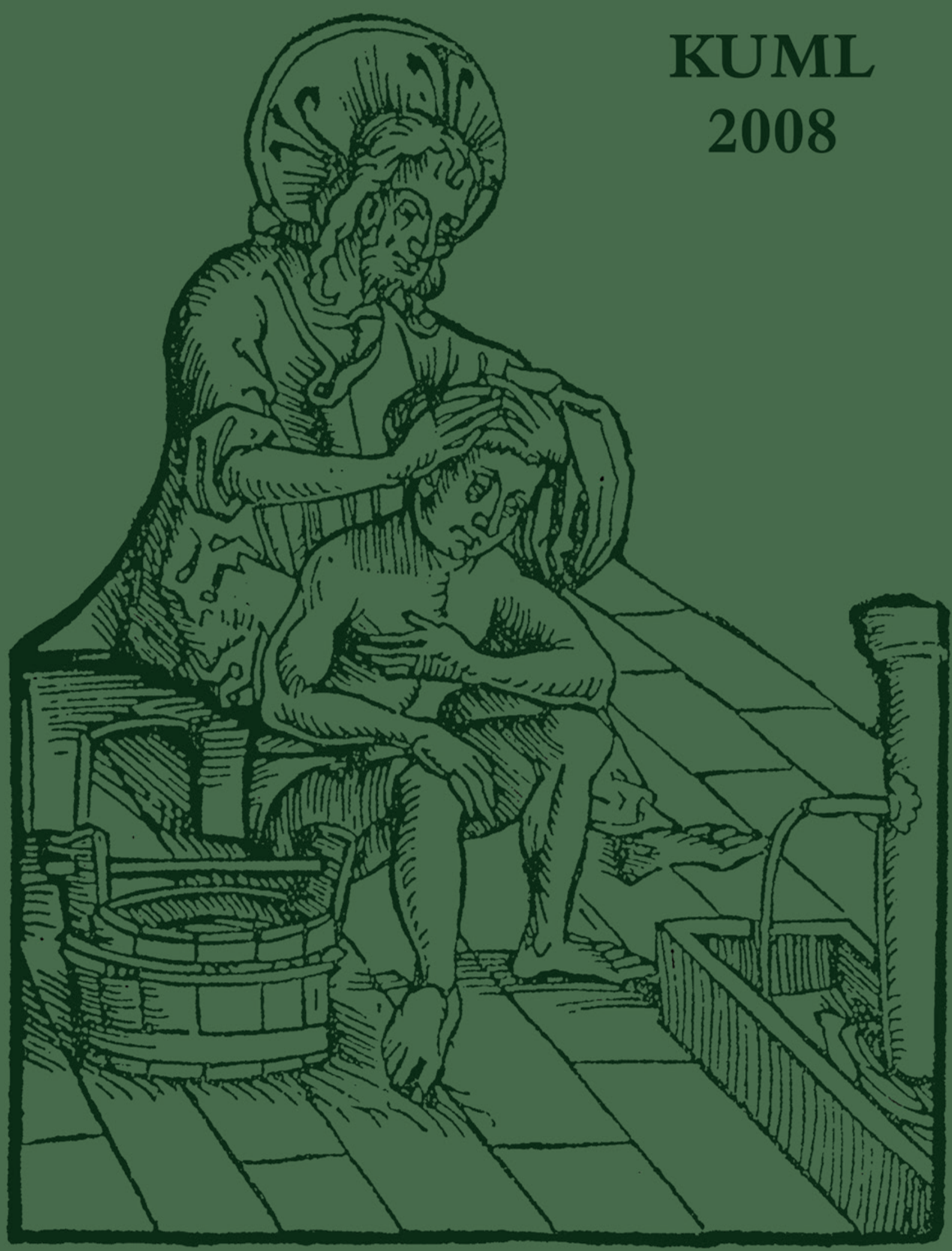




\section{KUML 2008 \\ Årbog for Jysk Arkæologisk Selskab}

With summaries in English

I kommission hos Aarhus Universitetsforlag 


\title{
Sikre fortidsminder
}

\author{
Svar på forrige indlæg
}

\author{
Af TORBEN DEHN, SVEND ILLUM HANSEN \& JØRGEN \\ WESTPHAL, KULTURARVSSTYRELSEN
}

Bevaringsforholdene for oldtidens store stengrave nåede et lavpunkt i slutningen af 1800 -tallet. $90 \%$ af de, anslået, oprindeligt mere end 30.000 anlæg var allerede forsvundet. Og mangelfulde fredningsbestemmelser gjorde, at kun et fătal af de resterende $10 \%$ var under beskyttelse. Resten var overladt til ejernes ve og vel, og det betød, at mange stengrave blev brugt som stenbrud og efterladt i mere eller mindre ruineret tilstand.

Men efterhånden ændrede indstillingen til oldtidens monumenter sig. I årtierne omkring år 1900 blev mange dysse- og jæettestuekamre udgravet - ofte i forbindelse med at gravhøje blev erkendt som stengrave. I forlængelse af undersøgelserne blev en del af anlæggene istandsat, og der blev etableret adgangsordninger for publikum. Ved en ændring af naturfredningsloven i $1937 \mathrm{blev}$ alle synlige fortidsminder fredet.

Omkring 100 restaureringsprojekter blev gennemført i perioden 1900-1950. I en årrække herefter var indsatsen mere sporadisk og begrænset, og forfaldet af storstensgravene accelererede. Derfor greb man fra slutningen af 1980'erne atter problemerne systematisk an. I de forløbne 20 år er yderligere mere end 100 anlæg blevet istandsat og sikret. I flere tilfælde har der blot været tale om mindre reparationer, mens arbejdet med de mere beskadigede anlæg ofte har været forbundet med store tekniske udfordringer. Generelt gælder det, at hvis en jættestuekonstruktion er forblevet uforstyrret siden byggeriet i yngre stenalder, er der som regel ikke bevaringsproblemer, men så snart et indgreb i konstruktionen har fundet sted - og der ikke er sket en retablering i overensstemmelse med konstruktionsprincipperne - er der åbnet mulighed for et accelererende forfald.

Hvordan restaurerer vi anlæggene, så de stadig kan besøges af publikum? Og hvordan sikres anlæggene, så de kan holde i flere tusinde år endnu? I en del tilfælde er stenkamre, plyndret for dæksten, blevet stabiliseret ved, at nye dæksten er blevet tilført. Nogle steder er hele stenkonstruktionen blevet yderligere dækket af en beskyttende høj med en græsklædt overflade. Det er klart, 
at indtrykket af en forfalds-romantisk megalitruin forsvinder, men ved forseglingen reduceres til gengæld erosion og nedbrydning betydeligt, både af selve stenene og af den konstruktion, som omgiver dem. Til glæde for både publikum og fremtidig forskning.

Som bekendt indebærer enhver arkæologisk udgravning en form for destruktion af det oprindelige. Det gælder selvfølgelig også, selv om det oprindelige stenalderanlæg er ødelagt så sent som i 1800-tallet. Derfor foretages restaureringsindgrebene i de fredede fortidsminder i mindst muligt omfang. Det skal her indskydes, at ordene vedligeholdelse, istandsættelse og restaurering ofte benyttes i flæng, men dette indlæg er ikke stedet til en nærmere diskussion heraf, ligesom problematikken med bevaring af senere tiders aktiviteter ikke berøres.

Oftest arbejdes der i eksisterende plyndringshuller eller udgravningsfelter fra nyere tid, sådan at flest mulige af anlæeggets intakte dele lades urørte. Det tilstræbes, at restaureringsarbejdet integreres med arkæologiske undersøgelser. Restaureringsindgrebene og de afledte arkæologiske observationer dokumenteres i form af tegninger, beskrivelser og fotos. Som et følgeprodukt af restaureringerne har disse undersøgelser i de seneste år givet et stort videnskabeligt udbytte med hensyn til stengravenes arkitektur og konstruktion, som har vist sig at være både meget avanceret og kompliceret. Denne viden om konstruktionsprincipperne benyttes i bevaringsarbejdet. Resultaterne er blevet formidlet både videnskabeligt og populært, hvilket har bevirket, at arbejdet med de store stengrave i Danmark er blevet kendt, også uden for landets grænser.

Den anvendte metode er i konflikt med $\$ \$ 9$ og 12 i Venezia-charteret fra 1964, hvorefter de elementer, der ved restaureringen tilføjes bygningsværket, ikke må kunne opfattes som oprindelige. I 1990'erne blev denne konflikt beskrevet og præsenteret i kollegiale forsamlinger i både ind- og udland, ligesom den i 1995 blev fremlagt for det daværende Kulturhistorisk Råd, som var rådgivende organ for Skov- og Naturstyrelsen. Ingen steder var der modstand mod restaureringsmetoden, idet den skønnedes bevaringsmæssigt optimal. I en kommenteret udgave af chartret hedder det da også om bestemmelserne i $\int 9$, at det må "forekomme rigtigt at give det nye en sådan udførelse, at det adskiller sig fra det gamle, men i praksis er dette selvsagt såre vanskeligt. I mange tilfælde må man forlade sig på, at der publiceres dokumentationsmateriale, der kan give alle interesserede besked om, hvad der er gammelt, hvad der er rekonstrueret med hold i dokumentarisk materiale, og hvad der er nyt." (Venedig-Charteret 1975, s. 16).

Udgangspunktet for restaureringsarbejdet er bevaring af mest muligt af det originale monument. Rekonstruktioner udføres kun i det omfang, det er på- 
krævet af hensyn til sikkerhed og holdbarhed. Der benyttes fortrinsvis naturens egne materialer. Alle tilførte materialer bliver beskrevet og dokumenteret. Ødelagte fliseopbyggede tørmure i stengravene suppleres med tilførte Neksøsandsten, som på bagsiden forsynes med mørtel - både som sikring og som markering af, at der er tale om en moderne istandsættelse. De store tilførte moræneblokke bliver forsynet med et emblem af rustfrit stål et diskret sted på stenen. Endelig bliver restaureringerne altid beskrevet i rapporter, sådan at man med sikkerhed kan afgøre hvilke elementer, der er originale og hvilke, der er tilførte eller ændrede.

Kulturarvsstyrelsen har i dag ansvaret for fortidsmindernes tilstand. En lille håndfuld specialister, som på baggrund af års erfaring er i stand til at bedømme en storstensgravs bevaringstilstand og sikkerhed, er ansat her.

Og det var heldigt i et tilfælde på Lolland i foråret 2008, hvor der fra den kommunale plejemyndighed indløb en anmeldelse om en livsfarlig jættestue ved Toreby (sb. nr. 070619-61). Allerede dagen efter var en medarbejder fra Kulturarvsstyrelsen på stedet og konstaterede, at jættestuen bogstavelig talt var en dødsfælde. Yderligere erosion af en gammel, og allerede kendt skade, betød, at jættestuens ene dæksten uden varsel ville kunne falde ned i kammeret. Da man alligevel var på stedet, blev også nabojættestuen Barneshøj (sb. nr. 070619-53) undersøgt. Det viste sig uhyggeligvis, at den var næsten lige så farlig. Derfor blev der rekvireret en mobilkran, som kunne løfte dækstenene af og lægge dem på jorden. At jættestuerne var i overhængende fare for at styrte sammen, viste sig ved, at et par af sidestenene herefter straks væltede af sig selv. Der var offentlig adgang til jættestuerne, og særligt Toreby-jættestuen blev flittigt besøgt af egnens børn samt en del turister. Der er afsat tid og penge til istandsættelse og sikring af de to jæettestuer i 2009.

\section{LITTERATUR}

Venecia-Charteret om bevaringarbejde. Fonden for Dansk Bygningskultur. København 1975. 